\title{
JNPH
}

Volume 7 No. 2 (Oktober 2019)

(C) The Author(s) 2019

\section{PROFIL BIERNACKI REACTION PADA PEKERJA CAR PAINT DI BENGKULU}

\section{PROFILE OF BIERNACKI REACTION IN CAR PAINT WORKERS IN BENGKULU}

\author{
RADEN SUNITA, RESVA MEINISASTI \\ POLTEKKES KEMENKES BENGKULU
}

\begin{abstract}
ABSTRAK
Latar Belakang : Biernacki Reaction merupakan kecepatan pengendapan sel-sel eritrosit di dalam tabung yang berisi darah dalam waktu satu jam yang telah diberi antikoagulan. Pekerjaan pengecat mobil merupakan salah satu jenis pekerjaan yang berisiko besar akan terjadinya gangguan kesehatan. Bahan yang digunakan banyak mengandung bahan kimia yang berbahaya, bahan tersebut berupa timbal. Timbal yang terserap oleh darah akan berikatan dengan sel darah merah dan dapat mengakibatkan gangguan pada proses sintesis hemoglobin $(\mathrm{Hb})$. Metode : Penelitian ini menggunakan desain penelitian deskriptif. Jumlah sampel dalam penelitian ini adalah 33 subyek dengan metode Total sampling. Metode pemeriksaan menggunakan metode westergreen. Hasil : Hasil penelitian ini menyatakan pada pekerja car paint menunjukkan Biernacki Reaction normal sebanyak 23 subyek $(69,7 \%)$ sedangkan Biernacki Reaction yang melebihi batas normal yaitu sebanyak 10 subyek (30,3\%) Kesimpulan : hasil pemeriksaan Biernacki Reaction sebagain kecil melebihi batas normal akibat paparan zat kimia pada cat mobil.
\end{abstract}

\section{Kata Kunci: Biernacki Reaction, Car Paint}

\begin{abstract}
Background: Biernacki Reaction is the speed of deposition of erythrocyte cells in a tube containing blood within one hour that has been given anticoagulants. Car painting work is one type of work that is at high risk of health problems. The material used contains a lot of hazardous chemicals, such materials are in the form of lead. Lead that is absorbed by blood will bind to red blood cells and can cause interference with the process of hemoglobin synthesis $(\mathrm{Hb})$. Method: This research uses descriptive research design. The number of samples in this study were 33 subjects with a total sampling method. The inspection method uses the WestGreen method. Results: The results of this study stated that the car paint workers showed normal Biernacki Reaction as many as 23 subjects $(69.7 \%)$ while Biernacki Reaction that exceeded the normal limit of 10 subjects $(30.3 \%)$ Conclusion: the results of the Biernacki Reaction examination were smaller than the limit normal due to exposure to chemicals in car paint.
\end{abstract}

Keywords: Biernacki Reaction, Car Paint 


\section{PENDAHULUAN}

Biernacki Reaction ,atau Erythrocyte sedimentation rate (ESR) atau sedimentation rate (sed rate) adalah kecepatan pengendapan sel-sel eritrosit di dalam tabung yang berisi darah dalam waktu satu jam yang telah diberi antikoagulan. Laju endap darah juga didefinisikan sebagai kecepatan pengendapan sel-sel eritrosit dalam plasma. Peningkatan nilai Biernacki Reaction menunjukkan suatu proses inflamasi dalam tubuh seseorang, baik inflamasi akut maupun kronis, atau adanya kerusakan jaringan (Utami, 2017). Proses Biernacki Reaction dapat dibagi dalam 3 tingkat yaitu: tahap pertama yaitu tingkatan pengumpulan atau tahap membentuknya gulungan pada eritrosit (rouleaux), tahap kedua yaitu tingkatan pengendapan cepat atau eritrosit mengendap secara tetap dan lebih cepat, tahap ketiga yaitu tingkatan pemadatan atau pengendapan gumpalan eritrosit mulai melambat karena terjadi pemadatan eritrosit yang mengendap. Internasional Committee Standarization Hematologi (ICSH) menerangkan bahwa metode yang disarankan dalam pemeriksaan Biernacki Reaction adalah metode Westergreen (Wiratma, 2017).

Pekerjaan pengecat mobil atau Car Paint merupakan salah satu jenis pekerjaan yang berisiko besar akan terjadinya gangguan kesehatan pada pekerja. Hal ini dikarenakan cat yang digunakan banyak mengandung bahan kimia yang berbahaya bagi kesehatan. Tahapan pekerjaan pengecatan mobil ini dimulai dari pengamplasan, pendempulan, pengecatan dasar dan pengecatan warna dengan masing-masing tahapan tersebut memiliki risiko terjadinya gangguan kesehatan terhadap tenaga kerja (Hikmawan et al., 2013).

Cat merupakan campuran bahan kimia yang sudah dikenal sejak dahulu dan banyak digunakan di berbagai tempat dan berbagai industri salah satunya adalah bengkel pengecatan (body repair) untuk mewarnai mobil. Cat ini merupakan bahan yang mudah menguap dan biasanya yang digunakan dalam bengkel adalah cat dalam bentuk cat semprot.
Cat semprot akan mengubah substansi menjadi bentuk aerosol yang mudah terisap (Grafina, 2013). Bahan utama dalam pengecatan mobil adalah isocynate. Bahan isocynate ini dapat bermanifestasi menjadi toksisitas akut maupun kronis. Pada toksisitas akut, para pekerja pengecatan mobil dapat mengalami iritasi mata, hidung, dan tenggorokan yang dapat disertai dengan batuk dan sesak napas. Sedangkan toksisitas kronis dapat dikaitkan dengan gangguan lesi paru, nasal dan imun. Gangguan paru pada inhalasi kronis zat ini umumnya mengalami ciri-ciri berupa sesak napas dan konstriksi bronchial yang bersifat kronis (Bagus et al., 2014).

\section{METODE PENELITIAN}

Penelitian ini menggunakan survei deskriptif. Sampel penelitian ini diambil dengan metode Total Sampling yang berupa seluruh populasi terdiri dari 30 orang responden. Metode yang digunakan untuk pemeriksaan Biernacki Reaction adalah metode Westergreen.

\section{HASIL PENELITIAN}

\section{Tabel 1 Profil Biernacki Reaction}

\begin{tabular}{ccc}
\hline Biernacki Reaction & Frekuensi & $(\%)$ \\
\hline Normal & 23 & 69,7 \\
\hline Tidak Normal & 10 & 30,3 \\
\hline Jumlah & 33 & 100 \\
\hline
\end{tabular}

Berdasarkan tabel di atas dapat dilihat bahwa profil Biernacki Reaction sebanyak 23 subyek normal $(69,7 \%)$ dan 10 subyek $(30,3 \%)$ pekerja car paint memiliki Biernacki Reaction tidak normal.

\section{PEMBAHASAN}

Berdasarkan penelitian yang telah dilakukan bahwa profil Biernacki Reaction sebanyak 23 subyek normal $(69,7 \%)$ dan 10 subyek $(30,3 \%)$ pekerja car paint memiliki Biernacki Reaction tidak normal. Hal ini dikarenakan tingkat kesadaran pekerja 
bengkel terhadap kesehatan sudah cukup tinggi, dan juga dapat dilihat bahwa responden bukan termasuk kategori perokok berat. Perilaku hidup sehat juga dilakukan pekerja bengkel pengecatan tersebut dengan cara beristirahat yang cukup, selalu meminum susu pada saat setalah melakukan pengecatan kendaraan, dan pada saat melakukan kegiatan pengecatan mobil pekerja bengkel juga selalu memakai alat pelindung diri (APD) yang lengkap berupa masker, sarung tangan, pelindung mata, baju pelindung, dan sepatu boot sehingga tingkat terpaparannya dari bahan kimia dalam cat tidak terlalu besar serta tidak terhirup langsung kepada pekerja, dan didapatkan sebanyak 10 orang (Sebagian kecil) pekerja bengkel pengecatan memiliki Biernacki Reaction tidak normal hal ini dikarenakan faktor usia,, kurangnya menjaga asupan makanan, kelelahan pada saat bekerja, kurangnya waktu untuk istirahat tidur, dan peradangan pada tubuh.

Peradangan dalam tubuh ini bisa disebabkan karena bahan utama dalam pengecatan mobil ini berupa isocynate. Bahan isocynate ini dapat bermanifestasi menjadi toksisitas akut maupun kronis. Pada toksisitas akut, para pekerja pengecatan mobil dapat mengalami iritasi mata, hidung, dan tenggorokan yang dapat disertai dengan batuk dan sesak napas. Sedangkan toksisitas kronis dapat dikaitkan dengan gangguan lesi paru, nasal dan imun.

Penelitian serupa juga dilakukan oleh (Rachmawati et al., 2016) dengan judul Perbedaan Laju Endap Darah Sebelum Dan Sesudah Pemberian Air Kelapa Hijau (Cocos Nucifera L) Pada Pekerja Bagian Pengecatan Industri Karoseri Semarang, menunjukkan bahwa tidak ada perbedaan laju endap darah baik antara sebelum dan sesudah pemberian air kelapa hijau pada pengukuran 1 jam dan 2 jam pada pekerja di bagian pengecatan. Dengan pemberian air kelapa hijau hanya dapat menurunkan laju endap darah sebesar $28,13 \%$ untuk pengukuran 1 jam dan terjadi penurunan sebesar $40,63 \%$ untuk pengukuran 2 jam.

Peningkatan nilai Biernacki Reaction dapat disebabkan oleh beberapa faktor yaitu jumlah eritrosit kurang dari normal, ukuran eritrosit yang lebih besar dari ukuran normal, peningkatan kadar fibrinogen dalam darah, tabung pemeriksaan digoyang atau bergetar, suhu dan pengaruh sinar matahari. Sedangkan faktor penurunan Biernacki Reaction yaitu lekositosis berat, polisitemia, abnormalitas protein (hyperviskositas, faktor teknis (problem pengenceran darah sampel beku, tabung Biernacki Reaction pendek, getaran pada saat pemeriksaan). Tinggi rendahnya nilai LED dipengaruhi oleh keadaan tubuh, terutama pada saat terjadi radang. Akan tetapi pada orang anemia, pada lansia, orang hamil (trimester kedua dan ketiga) dan penyakit tuberkulosis (TBC) memiliki nilai Biernacki Reaction yang tinggi. Sehingga pada orang normal dengan memiliki Biernacki Reaction tinggi dan sebaliknya, Biernacki Reaction normal belum tentu tidak ada masalah (Ariani et al., 2017).

Biernacki Reaction atau Laju endap darah (LED) adalah kecepatan pengendapan eritrosit dari sampel darah yang diperiksa dalam suatu alat tertentu yang dinyatakan dalam $\mathrm{mm}$ per jam. Biernacki Reaction menggambarkan komposisi plasma dan perbandingan antara eritrosit dan plasma. Darah dengan antikoagulan yang dimasukkan dalam tabung berlumen kecil dan diletakkan tegak lurus akan menunjukkan pengendapan eritrosit dengan kecepatan yang disebut Biernacki Reaction. Nilainya pada keadaan normal relatif lebih kecil karena gravitasi diimbangi oleh tekanan keatas (Martanti et al., 2017) Pengukuran Biernacki Reaction dapat dipengaruhi oleh faktor eritrosit, faktor plasma dan faktor teknik (Ariani et al., 2017). Pekerja bengkel pengecatan mobil merupakan salah satu pekerjaan yang berhubungan langsung dengan bahan kimia. Cat merupakan salah satu sumber pemaparan timbal karena digunakan untuk bahan pigmen dalam cat (Eka et al., 2017). Timbal dapat menyebabkan hemolisis eritrosit dan menghambat pembentukan hemoglobin. Timbal menyebabkan terganggunya pembentukan enzim G-6PD dan penghambatan enzim 
pirimidin-5'-nukleotidase di dalam tubuh. Hal ini menyebabkan turunnya masa hidup eritrosit dan meningkatkan kerapuhan membrane eritrosit sehingga terjadi penurunan jumlah eritrosit. Bila terdapat sangat banyak eritrosit maka laju endap darah akan terjadi penurunan dan bila sangat sedikit eritrosit maka Biernacki Reaction akan mengalami peningkatan (Dwilestari et al., 2010).

\section{KESIMPULAN}

Berdasarkan hasil penelitian dan pembahasan profil Biernacki Reaction pada pekerja bengkel pengecatan mobil Kota Bengkulu dapat disimpulkan bahwa hasil pemeriksaan Biernacki Reaction sebagain kecil melebihi batas normal akibat paparan zat kimia pada cat mobil.

\section{SARAN}

Diharapkan kepada para peneliti yang akan datang untuk lebih mengembangkan lagi dari hasil penelitian yang sudah ada.

\section{DAFTAR PUSTAKA}

Bagus, I. G., Wijaksana, B. and Muliarta, I. M. (2014) 'Analisis Faktor Resiko Gangguan Fungsi Paru Pada Tenaga Kerja Pengecat Spray Mobil Di Daerah Gatsu Timur.'

Deviyanti Mala Grafina, I. M. (2013) 'Analisis Gangguan Fungsi Paru Pada Pekerja Di Bengkel Body Repair X Tahun 2013.' Available at: http://lib.ui.ac.id/naskahringkas/201509/S52993-Deviyanti Mala Grafina.

Dicky Y.Wiratma, A. S. (2017) 'Pengaruh Perbedaan Metode Pemeriksaan Laju Endap Darah Terhadap Nilai LED Pasien Tersangka Penderita Tuberkulosis Paru Di UPT.Kesehatan Paru Masyarakat Dinas Kesehatan Provinsi Sumatera Utara', 56th Annual Conference of Metallurgists, 10(10), pp. 16-33. doi: 10.2527/jas2012-5761.
Dina Ariani, Puspawati, P. M. Y. O. (2017) 'Perbandingan hasil Pemeriksaan (LED) Pada Darah K2EDTA Tanpa Pengenceran Dengan Menggunakan Natrium Citrat 3,8\% Sebagai Gold Standar', (1).

Gandasoebrata, R. (2010) 'Penuntun Laboratorium klinik', 1, p. 620. doi: 10.1145/2505515.2507827.

Hendra Eka, J. M. (2017) 'Hubungan kadar timbal dalam darah dengan hipertensi pekerja pengecatan mobil di surabaya', 9, pp. 65-74.

Hermiranti Dwilestari dan Katharina Oginawati (2010) 'Analisis Hematologi Dampak Paparan Timbal Pada Pekerja Pengecatan (Studi Kasus: Industri Pengecatan Mobil Informal Di Karasak, Bandung)', pp. 17-18.

Martanti, E. T. et al. (2017) 'Vibration of Centrifuge Towords the Result of Erythrocyte Sedimentation Rate Examination Per 30 Cm', (1).

Muhammad Hikmawan, M.Furqaan Naiem, M. R. R. (2013) 'Faktor Yang Berhubungan Dengan Kejadian Kecelakaan Kerja Pada Pekerja Bengkel Pengecatan Mobil Di Kota Makassar', pp. 1-10.

Rachmawati, R. L. and Onny Setiani, Y. (2016) 'Perbedaan Laju Endap Darah Sebelum dan Sesudah Pemberian Air Kelapa Hijau (Cocos nucifera L) Pada Pekerja Bagian Pengecatan Di Industri Karoseri Semarang', Jurnal Kesehatan Masyarakat, 4, pp. 897-904. Available at:

https://media.neliti.com/media/publicati ons/111070-ID-perbedaan-laju-endapdarah-sebelum-dan-s.pdf.

Setyoningsih, O. S., Setiani, O. and Darundari, Y. H. (2016) 'Hubungan Antara Paparan Timbal $(\mathrm{Pb})$ Dengan Laju Endap Darah Pada Bagian Pengecatan Industri Karoseri Di Semarang', Jurnal Kesehatan Masyarakat, 4, pp. 852-861.

Utami, D. P. (2017) 'Hubungan Paparan Pestisida Organofosfat dengan Laju 
Endap Darah ( LED ) pada Petani di Desa Sumberejo Kecamatan Ngablak Kabupaten Magelang ( Association Between Exposure Organophosphate Pesticides with Erythrocyte Sedimentation Rate ( ESR ) Among Farmers', Jurnal Kesehatan Masyarakat, 5. 